\title{
アトピー性皮膚炎の顔面潮紶に 対する温清飲の有用性の検討
}

\author{
東一紀 \\ The Therapeutic Effect of Unsei-in on Facial Redness \\ (Inflammatory Congestion) in Atopic Dermatitis \\ -A Clinical Study of 20 Cases-
}

\section{Kazunori HIGASHI}

M.D., Department of Dermatology, Kitasato University School of Medicine, 1-15-1, Kitasato, Sagamiharashi, Kanagawa 228, Japan

\begin{abstract}
The effectiveness of Kampo therapy for facial redness was studied in 20 cases of atopic dermatitis, using the Kampo extract Unsei-in (EK-57, etc.), which is known to have antiinflammatory and anti-allergic activities. Unsei-in was used without other Kampo extracts in 10 cases. Of these, marked improvement was observed in one case (10\%) and improvement in two cases $(20 \%)$, all of which improved within two weeks. Five cases did not respond to therapy, and the redness worsened in two cases. In ten other cases Unsei-in was used in conjunction with other Kampo extracts. Of these, improvement was observed in three cases (30\%). Adverse reactions such as redness over the entire body (one case; $5 \%$ ) and gastric pain (one case; $5 \%$ ) were also observed. Despite these reactions, Unsei-in was shown to be useful in the treatment of facial redness associated with atopic dermititis.
\end{abstract}

Key words: atopic dermatitis, facial redness, Unsei-in

Nihon Toyo Igaku Zasshi (Japanese Journal of Oriental Medicine), 46, 753-760, 1996 (accepted 25 Oct, 1995)

\section{はじめに}

本論文では潮紅を炎症性允血と定義し，非炎症 性血管拡張と区別する。

アトピー性皮膚炎の患者とくに成人の患者の顔 面には，しばしば他の部位よりも明らかな潮紅を 認める。その理由として，顔面は1）ダ二，八ウ スダストなどの抗原に曝露されやすい。2）日
光，化粈などの外的刺激をらけやすい。3）皮裴 の細菌の增殖により湿潤性挤変や浮腫性紅斑が出 玩または埥化しやすい1。4）ステロイド外用剂

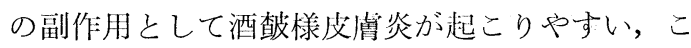
となどが考えられる。

最近, 漢方执よび皮膚科領域ではアトピー性皮 膚炎の顔面潮紅ないし類縁病变に対する漢方治療 の報告が行われている2 2 -5)。筆者はすでに顔面潮

医，北里大学医学部皮虐科，神奈川（問合せ先は自宅：

[1995年10月25日受理] 
紅にカネボウ温清飲が奏効した 1 例5)を報告し た。今回アトピー性皮膚炎の患者 20 症例を対象と して，顔面潮紅に対して温清飲を投与してその臨 床的有用性を検討したので報告する。

\section{対象と方法}

\section{1 対 象}

顔面の潮紅を主症状または主訴の一つとするア トピー性皮膚炎の患者のうち，他の治療によって アトピー性皮膚炎の症状が比較的安定した患者を 対象とした。な打顔面よりも他の部位の潮紅が強 い症例，顔面に湿潤や苔痽化などを伴う症例も対 象に含めた。

また，下記の患者を除外症例とした。

1）顔面の非炎症性血管拡張が強いために, 潮 紅の重症度の評価が明らかに困難であると思 われた症例。

2 ）顔面の潮紅部に明らかな細菌感染の合併を 疑った症例（細菌検査と抗生剤の投与を優先 した)。

3）顔面の接触皮膚炎（の合併）を疑った症例 (パッチテストによる診断確定を優先した)。

4) 光線過敏症 (の合併)を疑った症例（検査 を優先した)。

5 ）酒㭛様皮膚炎を疑った症例（ステロイド外 用剂からの離脱を優先した)。

6 ）試験期間内に顔面潮紅が改善しても, 温清 飲の薬効以外の他の要因, すなわち(1)自然経 過，(2)悪化因子の除去または改善 因子の負 荷, (3)併用治療の単独の効果, などによる改 善の可能性を除外することが困難であると予 想された患者。たとえば，

a . 試験前 4 週間以内に潮紅が出現または急 激に悪化した患者（1)，(2)による改善の可 能性が除外できない)。

b. 試験前 2 週間以内に潮紅が改善した患者 (1), (2), (3))。

c. 試験前 2 週間未満に潮紅に対する治療内 容を変更した患者(3)。ただし，治療の中 止，減量および使用頻度を減らすことは可 とした。 d. 試験前 2 週間以内にステロイド剂を内服 または注射した患者。

e . 例年潮紅が改善する時期と試験期間が重 なった患者(2))。

f . 転居など大きな環境の変化が起った時期 と試験期間が重なった患者(2)。

などである。

7 ）との他, 筆者が本試験に加えることを不適 当と判断した患者。

2 温清飲の投与方法・投与期間

試験した漢方製剂はカネボウ温清飲エキス顆粒 (成人 1 日量 $6.0 \mathrm{~g}$ ), ツムラ温清飲エキス顆粒 （1日量 $7.5 \mathrm{~g}$ ) または本草温清飲エキス顆粒（1 日量 $7.5 \mathrm{~g}$ ) である（いずれも 1 日分が 3 包であ る)。

投与方法は原則として下記の基準に従い，2 週 間以上投与することにした。

体重 $40 \mathrm{~kg}$ 以上: 温清飲エキス顆粒 1 日 3 包分 3 食前投与。

体重 20 40kg：1日 2 包分 2 食前投与。

体重 $20 \mathrm{~kg}$ 未満：1日 1 包分 2 または分 3 食前 投与。

また下記の例では慎重に投与することにした。

1) 中等度以上の虚証 (地黄による胃腸障害の 可能性があるため)。ただし陰陽虚実の判定 は松田ら ${ }^{6)}$ の記述による。

2 ）甚だしい陽実証（四物湯による炎症の悪化 の可能性 ${ }^{7}$ があるため)。

3) 顔面などに陽実証病態すなわち温熱により 悪化する強い炎症を認める(同上)。

3 併用治療

併用可能な治療薬は, 試験の 2 週間以上前から 使用していた下記の薬剤に限ることにした。すな わち外用剤は抗生剂, 抗菌剂, 漢方外用剂を除く あらゆる外用剂であり，内服剂は抗ヒスタミン 剂, 抗アレルギー剂または漢方内服薬（以下，漢 方薬）に限ることにした。また試験期間内にこれ らの薬剂の使用量または頻度を増加しないことに した。

その他のアトピー性皮膚炎の治療一ステロイド 剂内服, 抗生剂内服, ヒスタミン加人免疫グロブ 
リン皮下注治療などを併用しないことにした。

4 観察項目

主な観察項目は顔面潮紅の重症度であり, 下記 の 4 段階で評価した。

重度。中等度。軽度。軽微またはなし。顔面の 櫁痒, ほてり感なども観察した。

温清飲扣よび併用薬（とくに顔面の外用剤）の 使用状況を確認した。

副作用は試験期間内に現れた副作用を検討し た。

\section{5 判 定}

効果判定は下記の 5 段階で行った。

著効 : 試験開始時の中等度以上の顔面潮紅が消 退し, 顔面の外用治療から注济離脱しえ た場合。

有効：試験開始時と比較して, 顔面潮紅の重症 度が 1 段階以上の改善。

やや有効：1段階未満の改善。

無効 : 不変。悪化。副作用による試験の中止。 判定不能 :

1）副作用以外の理由で試験を中止した場 合。

(1) 患者が投与後 2 週間未満に来院しなく なった場合（脱落）。

(2) 試験薬の内服が困難な場合など。

2) 治療方法の違反

(1) 試験薬の投与方法（前述）の違反。

(2) 併用治療（前述）の違反。

3）下記の要因によって潮紅が改善した可能 性が多いと考えられる場合。

(1) 自然経過。

(2) 悪化因子の除去。

(3) 改善因子の負荷。

4 ） その他, 筆者が効果判定が困難であると 判断した場合。

やや有効以上の有効例に扣ける, 投与後効果が 出現するまでの期間を効果出現時期とした（必ず しも効果判定時期と一致しない)。

\section{結 果}

平成 2 年 4 月より 6 年 12 月までの間に, アトピ
一性皮膚炎の患者25例以上に対して温清领を投与 した。らち判定不能例を除く20症例を解析対象と した。らち温清飲を単独で使用した例は10例，他 の漢方薬を併用した例は10例であり，各症例の背 景因子，効果判定などを表 1 抢よび表 2 に示し た。な敃症例11はすでに報告した ${ }^{5)}$ 。施設別では 北里大学 16 例, 浅井皮膚科（川崎市） 2 例, 横浜 ぴ拉シティ東洋診療所 2 例であった。

試験成績は, まず温清飲単独使用10例では著効 1 例, 有効 2 例, 無効 7 例 \{不変 5 例, 悪化 1 例 (症例 6 ), 副作用による中止 1 例(症例 9 )\} であ った。悪化の理由は自然経過であると思われた。 有効以上の有効率は $30 \%$ であった。効果出現時期 はいずれも投与後 2 週間以内であり, 効果判定時 期と一致した。な和無効 1 例（症例 5 ）はその 後, 黄連解毒湯を追加して有効であった。

次に，温清飲と他の漢方薬を併用した10例では 有効 3 例, やや有効 3 例, 無効 4 例 \{不变 3 例, 副作用による中止 1 例（症例19）\}であった。有 効率は有効以上 $30 \%$, やや有効以上 $60 \%$ であり, 効果出現時期は投与後 10 日か.ら 4 週間以内であ り, 効果判定時期も 4 週間以内であった。

副作用は20例中 2 例 (10\%) に起こった。症例 9 は内服直後より全身の紅斑が著明に悪化し， 2 週間服用を続けても改善しなかったため投与を中 止し，その後改善した。また症例19は胃痛を起こ したため中止した。いずれも再投与による確認は していない。

\section{考 察}

アトピー性皮膚炎の顔面潮紅を対象として温清 飲を投与し，その臨床的有用性を検討した。その 結果, まず温清飲単独使用10例については，著効 1 例，有効 2 例（合せて $30 \%$ ）であり，効果出現 扣よび判定時期はいずれも投与後 2 週間以内であ った。有効以上 $30 \%$ という有効率はけっして高い とはいえないが, 自然経過, 覀化因子の除去, 併 用薬の単独の効果など他の要因による改善の可能 性をできる限り除外したら党で, 難治性といわれ ているこの潮紅の $30 \%$ が投与後 2 週間以内に明ら かに改善したことは，温清飲の有用性を示するの 
表 1 症例一覧(1) 一温清飲を単独で使用した例

\begin{tabular}{|c|c|c|c|c|c|c|c|c|c|c|c|c|}
\hline \multirow[b]{2}{*}{ No. } & \multirow[b]{2}{*}{ 年・性 } & \multirow[b]{2}{*}{ 証 ${ }^{6)}$} & \multirow[b]{2}{*}{ 随伴症状 } & \multicolumn{2}{|c|}{$\begin{array}{l}\text { アトピー性 } \\
\text { 皮膚 炎 }\end{array}$} & \multicolumn{2}{|c|}{ 顔面潮紅 } & \multicolumn{2}{|c|}{ 併用薬剤 } & \multirow[b]{2}{*}{ 判定 } & \multirow{2}{*}{$\begin{array}{l}\text { 効果 } \\
\text { 出現 } \\
\text { 時週) }\end{array}$} & \multirow[b]{2}{*}{ コメント } \\
\hline & & & & $\begin{array}{l}\text { 有病 } \\
\text { 期間 } \\
\text { (年) }\end{array}$ & 重症 & $\begin{array}{l}\text { 有病 } \\
\text { 期間 } \\
\text { (年) }\end{array}$ & 重症 & 顔面の & $\begin{array}{l}\text { 内服 } \\
\text { 郕 }\end{array}$ & & & \\
\hline 1 & $22 \mathrm{~F}$ & 中間 & $\begin{array}{l}\text { 顔面のつっ } \\
\text { 感 }\end{array}$ & 2 & 軽 & 2 & 中 & ス & - & 著効 & 2 & 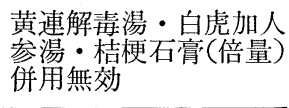 \\
\hline 2 & $16 \mathrm{~F}$ & $\begin{array}{l}\text { や } \\
\text { 陰虚 }\end{array}$ & - & 12 & 軽 & $?$ & 軽 & 非ス & - & 有効 & 2 & \\
\hline 3 & $26 \mathrm{~F}$ & $\begin{array}{l}\text { や户 } \\
\text { 陰虚 }\end{array}$ & $\begin{array}{l}\text { 顔面潮紅が } \\
\text { 令に悪化 }\end{array}$ & 16 & 軽 & 2 & 中 & 非ス & - & 有効 & 2 & \\
\hline 4 & $29 \mathrm{~F}$ & $\begin{array}{l}\text { や } \\
\text { 陰 }\end{array}$ & $\begin{array}{l}\text { 潮紅が月経 } \\
\text { 前に思化 }\end{array}$ & 26 & 軽 & $?$ & 軽 & 非ス & - & 無効 & - & \\
\hline 5 & $23 \mathrm{~F}$ & $\begin{array}{l}\text { や } \\
\text { 陰 }\end{array}$ & - & 18 & 軽 & 3 & 軽 & 非ス & 抗七 & 無効 & - & $\begin{array}{l}\text { 炎の後, 黄連解毒湯を } \\
\text { 追加して有効 }\end{array}$ \\
\hline 6 & $16 \mathrm{~F}$ & やや & $\begin{array}{l}\text { 潮紅が冬に } \\
\text { 徳化 }\end{array}$ & 12 & 軽 & 1 & 軽 & 非ス & 抗七 & 無効 & - & $\begin{array}{l}\text { 潮紅の悪化により中 } \\
\text { 止。自経過と思われ } \\
\text { た。 }\end{array}$ \\
\hline 7 & $16 \mathrm{~F}$ & $\begin{array}{l}\text { や户 } \\
\text { 陰虚 }\end{array}$ & - & 13 & 軽 & $?$ & 中 & 父就 & - & 無効 & - & 漢方諸治療無効 \\
\hline 8 & $17 \mathrm{~F}$ & $\begin{array}{l}\text { や户 } \\
\text { 陰虚 }\end{array}$ & $\begin{array}{l}\text { 潮組が冬に } \\
\text { 悪化 }\end{array}$ & 13 & 軽 & 1 & 中 & 永六 & - & 無効 & - & 漢方諸治療無効 \\
\hline 9 & $35 \mathrm{~F}$ & 中間 & $\begin{array}{l}\text { 潮紒が冬に } \\
\text { 悪化 }\end{array}$ & 2 & 軽 & 2 & 中 & 非久 & 抗ヒ & 無効 & - & $\begin{array}{l}\text { 全身の紅斑の悪化によ } \\
\text { わ中止。副作思わ } \\
\text { れた。 }\end{array}$ \\
\hline 10 & $33 \mathrm{~F}$ & $\begin{array}{l}\text { やや } \\
\text { 陰虚 }\end{array}$ & - & 33 & 軽 & 15 & 重 & 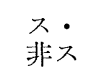 & 抗七 & 無効 & - & 漢方諸治療無効 \\
\hline
\end{tabular}

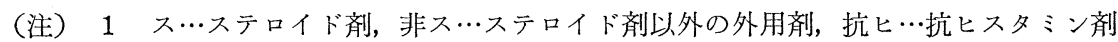

2 アトピー性皮膚炎の重症度

軽 症……dry skin が主体にて, 丘疹, 紅斑などの病変が限局性（たとえば関節部のみ）のもの 中等症……疹, 紅斑などの病巣が全身性にみられるが，苔癬化や湿潤病変などがみられても限局し ているもの

重 症……质疹, 紅斑などの病巣が全身性に多発し，さらに苔癬化や湿潤病変などが甚だしいもの （北里大学皮膚科学教室 分類）

\section{として評他してよいと考えられる。}

作用治䝤としては, 外用剂は抗生剂, 抗菌剂, 菬方外用剂を除くあらゆる外用剂, 内服剂は抗七 スタミン剂，抗アレルギー剂（結果として併用例 なし）の併用を可とした。そして併用薬の単独の 効果による改善の可能性をできる限り除外するた めに，併用薬は試験の 2 週間以上前から使用して いた薬剤に限ることにした。また試験前 2 週間以 内に潮紅が改善した症例を除外症例とした。さら に試铪期間内に俾用薬の使用量・頻度を増加した
症例を判定不能と判定し，解析刘象から除外し た。要するに，他の治療を 2 週間以上前から継続 して潮紅が改善しなかったために温清飲を追加投 与した例，または他の治療の代りに温清飲を用い た例に対象症例を限ることにした。

な扮有効以上 3 例のうち症例 2,3 は, 潮紅が 温清飲の単独の効果で改善した可能性は少く, 抒 そらく温清飲と外用剂の複合効果によって改善し たのであろらと考兄られる。一方, 症例 1 は温清 领の単独の效果で改善したと思われる。 
表 2 症例一覧(2) 一温清飲と他の漢方薬を併用した例

\begin{tabular}{|c|c|c|c|c|c|c|c|c|c|c|c|c|}
\hline \multirow[b]{2}{*}{ No. } & \multirow[b]{2}{*}{ 年・性 } & \multirow[b]{2}{*}{ 証 } & \multirow[b]{2}{*}{ 随伴症状 } & \multicolumn{2}{|c|}{$\begin{array}{l}\text { アトピー性 } \\
\text { 皮膚 咨 }\end{array}$} & \multicolumn{2}{|c|}{ 顔面潮紅 } & \multicolumn{2}{|c|}{ 併用治療 } & \multirow[b]{2}{*}{ 判定 } & \multirow{2}{*}{$\begin{array}{l}\text { 効果 } \\
\text { 出現 } \\
\text { 時期 } \\
\text { (週) }\end{array}$} & \multirow[b]{2}{*}{ コメント } \\
\hline & & & & \begin{tabular}{l|} 
有病 \\
期間 \\
$($ (年)
\end{tabular} & 重症 & $\begin{array}{l}\text { 有病 } \\
\text { 期間 } \\
(\text { 年) }\end{array}$ & 重症 & $\begin{array}{l}\text { 顔面の } \\
\text { 用剂 }\end{array}$ & 内服剂 & & & \\
\hline 11 & $21 \mathrm{~F}$ & $\begin{array}{l}\text { や } \\
\text { 陽実 }\end{array}$ & 顔面の乾燥 & 10力月 & 軽 & 10力月 & 軽 & 非ス & 桔梗石膏 & 有効 & 2 & $\begin{array}{l}\text { 黄連解毒湯・桔梗 } \\
\text { 亮併用絯効 }\end{array}$ \\
\hline 12 & $21 \mathrm{M}$ & $\begin{array}{l}\text { や } \\
\text { 虚 }\end{array}$ & - & 19 & 軽 & 5 & 軽 & 非ス & $\begin{array}{l}\text { 黄連解毒 } \\
\text { 湯・抗ア } \\
\text { 枯梗石膏 } \\
\text { (倍量) }\end{array}$ & 有効 & 10日 & $\begin{array}{l}\text { 黄連解毒湯・桔梗 } \\
\text { 石管併戌效 }\end{array}$ \\
\hline 13 & $18 \mathrm{~F}$ & $\begin{array}{l}\text { や户 } \\
\text { 陰虚 }\end{array}$ & $\begin{array}{l}\text { 顔面潮紅.が } \\
\text { 経前に悪 } \\
\text { 化 }\end{array}$ & 4 & 中 & $?$ & 中 & 非ス & $\begin{array}{l}\text { 桂枝获苓 } \\
\text { 丸・抗ア } \\
\text { ナイスタ } \\
\text { チン }\end{array}$ & 有効 & 3 & \\
\hline 14 & $18 \mathrm{~F}$ & $\begin{array}{l}\text { や户 } \\
\text { 陰虚 }\end{array}$ & $\begin{array}{l}\text { 潮紅が冬に } \\
\text { 悪化 }\end{array}$ & 15 & 軽 & 8 & 中 & $\begin{array}{l}\text { 쟈⿱一土 } \\
\text { 的 }\end{array}$ & $\begin{array}{l}\text { 黄連解毒 } \\
\text { 湯・桂枝 } \\
\text { 茯苓丸・ } \\
\text { 抗ア }\end{array}$ & $\begin{array}{l}\text { p户 } \\
\text { 有効 }\end{array}$ & 4 & $\begin{array}{l}\text { 温清飲・黄連解毒 } \\
\text { 湯併無効 }\end{array}$ \\
\hline 15 & $23 \mathrm{~F}$ & $\begin{array}{l}\text { やや } \\
\text { 陰虚 }\end{array}$ & $\begin{array}{l}\text { 月経痛が強 } \\
\text { ． }\end{array}$ & 23 & 軽 & 1.5 & 中 & 非ス & $\begin{array}{l}\text { 黄連解毒 } \\
\text { 湯・桂枝 } \\
\text { 获苓丸・ } \\
\text { 抗ア }\end{array}$ & $\begin{array}{l}\text { p } \\
\text { 有効 }\end{array}$ & 2 & $\begin{array}{l}\text { 黄連解毒湯単独使 } \\
\text { 歹やや有効 }\end{array}$ \\
\hline 16 & $31 \mathrm{~F}$ & $\begin{array}{l}\text { や户 } \\
\text { 陰虚 }\end{array}$ & $\begin{array}{l}\text { 潮紅が月経 } \\
\text { 前に悪化 }\end{array}$ & 29 & 軽 & $?$ & 中 & 非ス & $\begin{array}{l}\text { 黄連解毒 } \\
\text { 湯・桔梗 } \\
\text { 石膏 (倍 } \\
\text { 量) }\end{array}$ & $\begin{array}{l}\text { や } \\
\text { 有効 }\end{array}$ & 4 & \\
\hline 17 & $21 \mathrm{~F}$ & 中間 & 月経痛が強 & 17 & 軽 & 10 & 中 & 非ス & $\begin{array}{l}\text { 桂枝获苓 } \\
\text { • 桃 } \\
\text { 承気湯 }\end{array}$ & 無効 & - & 漢方諸治療無効 \\
\hline 18 & $22 \mathrm{~F}$ & 中間 & - & 22 & 軽 & 3 力月 & 中 & 非ス & $\begin{array}{l}\text { 黄連解毒 } \\
\text { 湯・桔梗 } \\
\text { 石膏 }\end{array}$ & 無効 & - & 漢方諸治療無効 \\
\hline 19 & $19 \mathrm{~F}$ & $\begin{array}{l}\text { や } \\
\text { 陰虚 }\end{array}$ & $\begin{array}{l}\text { 潮紅が月経 } \\
\text { 前に悪化 }\end{array}$ & 12 & 中 & 3 & 中 & 非ス & $\begin{array}{l}\text { 黄連解毒 } \\
\text { 湯·皇虎 } \\
\text { 加人参湯 } \\
\text { 桂枝荓 } \\
\text { 丸・抗ア }\end{array}$ & 無効 & - & 胃痛にて中止 \\
\hline 20 & $36 \mathrm{M}$ & 中間 & - & 29 & 中 & 3 & 中 & 非ス & $\begin{array}{l}\text { 消風散・ } \\
\text { 黄連解毒 } \\
\text { 湯・抗ヒ・ } \\
\text { 抗ア }\end{array}$ & 無効 & - & 漢方諸治療無効 \\
\hline
\end{tabular}

（注） 1 抗ア…抗アレルギー剤

2 併用した漢方薬はすべて製剤である。

次に，他の漢方薬を併用した10例では，有効 3 例 $(30 \%)$, やや有効 3 例であり，効果出現抢よび 判定時期は投与後 4 週間以内であった。併用治療 として, 内服剂は抗ヒスタミン剤, 抗アレルギー 剂括よび漢方薬の併用を可としたが，漢方薬につ いては, 投与後 2 週以降に効果が出現する可能性 があるため, 併用した漢方薬の単独の效果で有効
と判定された可能性は必ずしも否定できない。し かし筆者の経験上, 本病態の漢方内服治療は投与 後 2 週以降よりも 2 週間以内に効果が出現する場 合が多いため, 他の漢方薬の単独の効果で奏効し た可能性は少いと考光られる。

また抗アレルギー剤は $2 \sim 3$ カ月間の長期使用 によって薬効が徐々に現れる場合があり，併用に 
より温清飲の効果判定を困難にする可能性が考兄 られる。しかしやや有効以上で抗アレルギー剤を 併用した 4 例では, 温清飲の投与前 2 週間以上の 間改善傾向はなく, 投与後 4 週間以内に改善し有 効と判定しえたことから, 抗アレルギー剂の単独 の効果で有効と判定された可能性は少ないと考光 られる。

副作用については，20例中 1 例（5\%）が全身 の紅斑の著明な悪化， 1 例 ( $5 \%$ ）が胃痛を起こ したが，いずれも投与を中止した後改善した。

症例 9 に和ける紅斑の悪化の原因については, 他の原因すなわち自然経過, 悪化因子の負荷, ス テロイド外用剂の中止，また薬疹が一応鑑別され たため, 温清飲の副作用であると考えた。な和瞑 眩8)の可能性については，2 週間以上内服を続け ても紅斑が改善せず，内服中止後に改善したこと より否定的である。おた発汗剂による炎症の一時 的な悪化 ${ }^{9)}$ 和よび熱剤による炎症の悪化は, 温清 飲は発汗剤と熱剤を含まないため否定される。

以上より温清飲はアトピー性皮膚炎の顔面潮紅 に対する有用な治療薬の一つであると考えられ た。

温清飲の使用目標, 薬理作用拈よび作用機序に ついては，前論文らで述べたので割愛する。

温清飲の副作用については，甚だしい陽実証ま たは局所の陽実証病態では, 四物湯の血行改善作 用による炎症の悪化が起こる可能性があり7)，交 た中等度以上の虚証では地黄による胃腸障害が起 こる可能性が多いため, これらの病態を慎重投与 項目として掲げた。しかし 1 例が全身の紅斑の著 明な悪化を起こし，また 1 例が胃痛を起こした。

副作用を予防しえなかったことについては，症 例 9 は思った以上の陽証であったため紅斑が悪化 したと考えられ，誤診・誤治である。なお本例が
夏に悪化しないのは冷房のきいた部屋にこもるた めであると思われた。また症例19はやや陰虚証で あったが，投与前に胃痛を起こすことを予想する のは筆者には困難であった。

最後に, 今回の症例はやや陰証, やや虚証また は中間証に偏ったが，温清飲の適応症をさらに明 確にするためには，今後除外項目之慎重投与項目 に該当する症例を除いた多数例の検討を，多角的 かつ経時的に行うことが必要であると考えられ た。また併用治療については, 内服剂は抗ヒスタ ミン剤のみとして，抗アレルギー剤と漢方薬を除 外すべきであると考苀られた。

\section{文 献}

1）野口俊彦, 他：成人型アトピー性皮膚炎の顔面酒

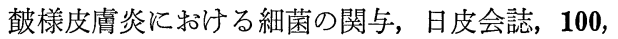
929 934, 1990

2 ）三田哲郎，他：アトピー性皮膚炎の顔面紅皮症型 皮疹に対する漢方治療の検討; 駆瘀血剂と清熱剂 の合方効果, 日本東洋医学雑誌, 45, 595 600, 1995

3）古江増隆, 他 : ツムラ通導散が奏効したアトピー 性皮膚炎，西日皮膚，55，275 277，1993

4）東一紀，他：アトピー性皮膚炎の顔面の発赤 （炎症性充血）飞対する黄連解毒湯と桔梗石毫の 有用性の検討，皮膚科紀要，88，391 401，1993

5 ）東一紀：アトピー性皮膚炎の顔面潮紅に温清飲 が奏効した 1 例，漢方の臨床，42，1057～1063， 1995

6）松田邦夫, 他: 臨床医のための漢方 ・基礎 編, pp. 7 11， カレントテラピー, 1987

7）松田邦夫：症例に上る漢方治療の実際, pp.369 371, 創元社, 1992

8 ）松田邦夫 : 瞑眩の臨床経験, 日本東洋医学雑誌, 24，441 444，1974

9）菊谷豊彦, 他：漢方薬の選び方・使い方, pp. 259 ２61, 医学書院, 1990

要旨 顔面の潮紅を主症状または主訴の一つとするアトピー性皮膚炎の患者20症例を対象と して，漢方製剤の温清领を投与してその臨床的有用性を検討した。温清飲を単独で使用した10 例では著効 1 例 (10\%), 有効 2 例 (20\%), 無効 7 例であり, 効果出現時期はいずれも投与後 2 週間以内であった。一方，温清飲と他の漢方内服薬を併用した10例では有効 3 例(30\%), や や有効 3 例, 無効 4 例であった。副作用は 2 例（10\%）飞起こり，全身の紅斑の著明な悪化 1 例, 胃痛 1 例であった。以上より温清飲はアトピー性皮膚炎の顔面潮紅に対する有用な治療薬 
の一つであると考えた。

キーワード: アトピー性皮膚炎, 顔面潮紅, 温清飲 